\title{
System Dynamic Model in Analyzing 5 Layers Basement Work
}

\author{
Divy Wira Agusma, and Albert Eddy Husin
}

Department of Master Program in Civil Engineering

Mercu Buana University

Jakarta Indonesia

\begin{abstract}
In connection with the increase in construction and the level of urbanization that occurs in Indonesia, the construction of highrise housing will be carried out to optimize narrow land in urban areas. By providing several facilities with the concept of high rise building in the basement area and building a layered basement, it is expected to optimize the available land for the development of high rise housing. This study determines the approach to rework analysis on a 5-layer basement with a Dynamic Model System simulation model that can provide superior estimates so as to produce scenarios to reduce rework costs. With this research update, it is estimated that the System Dynamic Model ensures that rework costs can be reduced on Basement 5 Layer work by $17.41 \%$ of the initial rework cost.
\end{abstract}

Key Words: High Rise Building, Basement, System Dynamic, Rework, Cost.

\section{INTRODUCTION}

Indonesia is a country with large and dynamic economic activities reflected by an average economic growth reaching $6 \%$ per annum [1]. With the increasing demand for housing in Indonesia, it has led to the adding number of building construction with the concept of vertical housing. Basement construction is a very important work item in the construction of high-rise housing that must be carried out every time the construction of a high-rise building with various facilities.

The lower level of the structure has a very important role in the structural system. The lower structure carries the loads of the structure above it, so the lower structure must not collapse before the upper structure. The substructure planning is need to be done very carefully considering the importance of this part of the construction. If the lower structure collapses then the sturdy building above it will also collapse (in vain). Underground or basement structures we often encounter in multistory buildings with large capacities making it possible to build basements. The basement function as a parking lot, Mechanical Electrical and Plumbing items facilities and needs, and some other functions.

Therefore, the basement is applied to save land area hence the construction of a multilevel basement is implemented. Basement construction is often an economical solution to overcome land limitations in building construction. According to the data from Arcadis Indonesia 2019, the cost of building a Basement ranges from IDR. 7.67 million to IDR. 9.40 million. Rework is a repetitive work caused by mistakes in a construction project. Rework is always taking place in construction activities with different values in each case. Construction projects often experience cost and schedule overruns where the rework is a significant factor that directly contributes to these overruns. The research done by the Construction Industry Institute (CII) reveals that direct costs caused by rework has cost $5 \%$ of total construction cost in average (CII) [3]. Rework has become one of the most common concerns in construction projects. In most cases, rework arises from changes, damages, defects, errors, omissions, and other nonconformances [4]. Reported costs of rework have been found to range from 3.5 to $25 \%$ of a project's contract [5]. A change order is "a written order to the contractor signed by the owner and architect, issued after execution of the contract, authorizing a change in the work or an adjustment in the contract sum or the contract Time"[6] . Change orders may result from a number of reasons such as a discrepancy in the design documents, change order instruction given by the owner, and unforeseen/differential site conditions. Change orders have a significant impact on project performance in terms of delay in project schedule, increase in cost through rework and decrease [6].

System dynamics as a methodology is based on systematic thinking for studying and improving the understanding of complex system. This method is feedback based and object oriented. In this approach, four different tools namely Storage, Run, Joints and Convertor are utilized [7]. SD modeling is an objected-oriented methodology in which cause and effect variables are 
arranged into a causal loop diagram (CLD) to represent the structure and interaction of principal feedback mechanisms in a system [8]. The SD approach is a powerful tool for understanding the behavior and expected trends related to changes in the dynamically complex systems. Therefore, it has been successfully applied in a wide variety of problems in the construction industry, such as resource management [9]. Dynamic System is a methodology for studying changes in the behavior of time from a system that is so complex, that it can be used to solve various kinds of problems in various fields. The dynamic system can perceive the problem as a whole. The purpose of the dynamic system method is to understand how the work of each element that can build a system, to optimize the work of the system (after understanding how each element of the system works), and to predict future system performance based on optimal work results.

\section{METHODOLOGY}

\subsection{Variable Value}

The need to prepare a "cause and effect" diagram to determine the value of this variables with the aim of knowing the initial hypothesis of a model that will be used as a tool to help simplify the variables analysis process that will later be reanalyzed. Causal diagrams are generated from several literature studies that have been verified by respondents. The verified causal diagram will then be converted into a Stock Flow Diagram (SFD). In this process, qualitative and quantitative value input is required.

\subsection{Model}

The first step in developing both linear and nonlinear deterioration models is to define CLDs that consist of variables connected by causal links whose polarities denote the effects of one variable connected by causal links whose polarities denote the effects of one variable on another. A positive link, i.e., (+) polarity, implies that the cause and effect are moving/changing in the same direction in the model: e.g., if a cause increases, the effect increases, and if a cause decreases, the effect are decreases [12]. The magnitude of the scenario influence is used as a Stock Flow Diagram (SFD) simulation to see how much the solution can reduce the amount of rework work.

The data that will be entered into the model are stock, flow, auxiliary, and constant. The simulation model is made based on the SFD containing the data, then the simulation is carried out in order to get the desired results. Before the simulation process is carried out, the first step is to determine the simulation specifications consisting of the simulation time range, integration method, and time step. Simulation is a dynamic process of model behavior which output is a time behavior graph and a time table. Model validation Model verification is done to check the suitability of the model that has been made with the applicable principles and also to evaluate 2.3.5. Stock-and-flow diagrams are composed of four fundamental concepts: stocks, flows, connectors, and converters. The combination can provide the tools needed to model problem situations, and they do so in a way that highlights the interactions and feedback loops that maintain the behavior [13] .

For the proposed system dynamics, the model validation was done by comparing the result of extreme scenarios. When there is an increase in earning, it will eventually lead to increase in fund balance [14]. Model testing can be done by testing the structure and behavior of the model. Model validation is a very important step in the system dynamics methodology.

\section{RESULTS}

The application of the dynamic system in this section is expected to minimize the cost of rework on the 5-layers basement work, so that it is in accordance with the predetermined literary norms and standards [15].

\subsection{Model Causal Loop Diagram}

The Causal Loop Diagram model in this study which identifies the work of the 5-layers Basement is determined by collective thinking, the model can represent each function contained in the 5-layer Basement work in particular,

\subsubsection{Variables - Variables contained in the Causal Loop Diagram}

- Additional staff

Human resources are a major influence on every construction project, with the presence of qualified human resources, the construction project can be managed according to the initial plan, with the additional staff on the foundation work of the bored 
pile, secant pile and pile cap of the 5-layers basement project, the project procedures can be optimized and implemented properly.

- Construction cost

Financial management in a project will determine the success of a project, with effective financial management and in accordance with the plan, it is expected to reduce the problems that occur in the foundation work of bored pile, secant pile and pile cap of the 5-layers basement project.

- Periodic discussion

In problem solving process, especially in construction projects that involve many stakeholders, it is very important to prioritize discussions in every problem solving in the project, therefore periodic discussions involving all stakeholders in a construction project are very important.

- Communication

With various educational backgrounds, the State and the thoughts of the parties involved in a communication project are one of the causes of problems that occur in a construction project, so by increasing maximum communication, it is hoped that disputes caused by bad communication will be resolved.

Planning

Before carrying out activities on a construction project, the planning stage is a very important thing to do so that the project can meet the expectations of all parties involved in the construction. In addition, before construction activities begin, the planning stage is also carried out for each activity in construction.

- Material

With bored pile foundation work, secant pile and pile cap in a very large 5-layers basement project, it also important to make sure sufficient material resources so that the possibility of project delays or project losses due to material unavailability can be avoided.

- Technology

With the rapid improvement happening in the world these days, especially in technology, the construction process, especially the bored pile, secant pile and pile cap work continues to be influenced by technology, technological knowledge must be possessed by every team folded in the foundation work of the bored pile, secant pile and pile cap of the 5-layers basement project.

- $\quad$ Staff Training

The skills possessed by each team in the project are a must in project completion, by having skills that is qualified or even more excel, the project can be completed while also performing regular training for each employee. The goal is to reduce the rework on the foundation work of bored pile, secant pile. and the pile cap of the 5-layer basement project.

- Finance

As it has commonly known, there are 3 things that greatly affect the project: cost, time and quality, meaning that the cost of the project is closely related to the financial condition of the project, including the financial condition of the owner, contractor or other involved parties.

- Design

In construction work there are several stages that must be carried out, design is a very important stage in the construction process, any errors occur in the design stages will have an impact that may lead to the rework on the foundation work of bored pile, secant pile and pile cap of the 5-layers basement project.

- Management Error

All policies and procedures applied in the foundation work of bored pile, secant pile and pile cap of the 5-layers basement project are called as management policies, if there is an error in the management policy, it will have an impact on the emergence of the rework and even a very big loss in the construction project. 


\subsection{Stock Flo Diagram}

Before determining the stock flow diagram in detail, the author first determines the classification of the division, in Figure 1.2 you can see the types of rework occurring as follows:

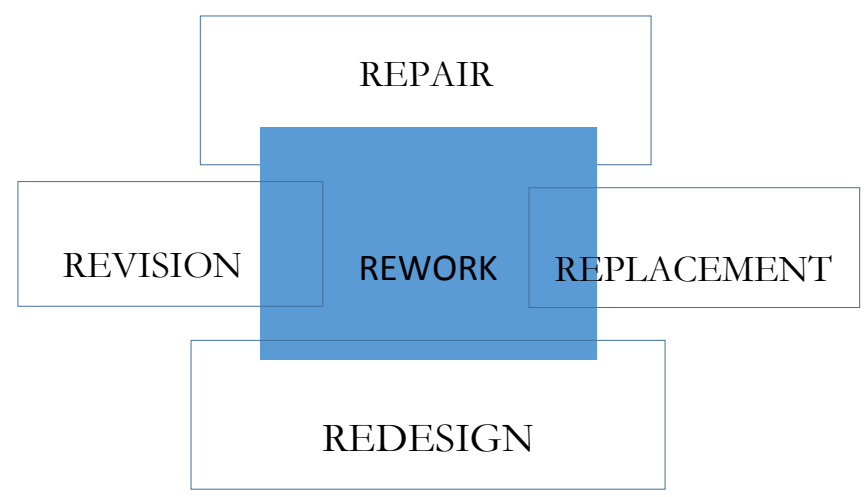

Figure 1.1 The scope of the rework according to Burrati et al., 1992

Types of rework according to (Burati, Farrington \& Ledbetter, 1992), namely:

a. Repair, the scope of repair includes rework to return the condition of a certain work item to its original condition (the work in question is already in a finished state).

b. Revision, the scope of revision includes work done to complete or improve work items that have changed as a result of the work execution process.

c. Replacement, is a repair work by replacing a unit of material or a work result because it does not function according to standards.

d. Redesign, is a repair activity carried out by the designer or implementer to redesign the design.

From the primary data obtained directly from the following field through interviews and filling out questionnaires, it is found that the factors that cause rework on the bored pile, pile cap and secant pile work in a 5-layers basement of a high-rise building which are some factors that influence the occurrence of rework on the bored pile foundation, pile cap and secant pile in 5layers basement. The questionnaires and interviews are conducted with experts who have experiences in completing high-rise building construction, especially the basement work. The factors that affect the occurrence of rework on 5-layers basement

\subsection{Repair}

- Management error

In the research analyzed, there were mismanagement that caused rework on the foundation work of bored pile, secant pile and pile in the 5-layer basement project.

- Speed-up time

Time is very important in project completion, in research, the rework often occurred because the acceleration plan is not planned properly.

- Staff Relocation

In order for the bored pile foundation work, secant pile and pile cap to be completed in accordance with the initial plan, staff requirements are very important in a project, in this study staff transfers that are often carried out by contractors have an impact on the quality of the field which causes the rework on the 5-layers basement project. 


\subsubsection{Replacement}

- Material replacement

In the implementation of the construction of bored pile foundation work, secant pile and pile cap in the 5-layers basement project, the availability of material and consistency in the use of the material is very important, in this study there is often material replacement in the field, so that it has an impact on the quality of the 5-layers basement project that caused the rework

- Technology Implementation

With technology that is very fast in this era, technology implementation must still be carried out a 5-layer basement project. In this study, the application of technology was not optimum, so that it had an impact on the necessity of a rework.

\subsubsection{Revision}

- Construction procedure

Appropriate procedures and plan suitability will have an impact on the success of a project. In this study, the procedures implemented were not in accordance with the initial plan, resulting in rework on the foundation work of bored pile, secant pile and pile cap in the 5-layers basement project.

- Project communication

Construction projects with a very difficult level of completion require smooth communication, based on research on bored pile, secant pile and pile cap foundation work in the 5-layers basement project of communication between personnel are not optimal, this situation leads to the rework.

- Social and culture

It is common for construction work to experience constraints due to social and cultural conditions at the project location, including a 5-layer basement project that may lead to the rework.

\subsubsection{Redesign}

- Contract Information

The contract is an important document prior to the commencement of construction work, with the contract being made and being able to explain the contents of the contract document to interested parties in the project in order to implement the contract information to reduce rework costs in the 5-layer basement work.

- Design knowledge

Design is an important process before construction is carried out. If the design is clear according to the required provisions and considering the actual conditions in the field, the occurrence of rework in a 5-layer basement construction project can be reduced.

\subsection{System Dynamic Modeling}

System dynamic modeling simulation is the main thing that must be done before deciding how much cost that would like to be reduced for rework on a 5-layers basement work. After analyzing and making a causal loop diagram that affects the occurrence of rework on on a 5-layers basement project, this research first uses experts in analyzing and determining factors that can reduce the occurrence of rework on the 5-layers basement

Based on the factors mentioned, this study can determine or provide 1 simulations that will become a reference in determining factors that can reduce the occurrence of a rework which includes:

Simulation : Carry out regular evaluations and meetings, add employees as needed, discuss and approach all staff involved, train all teams involved, give rewards in the form of bonuses and charter and budget for consumption costs in meetings.

\section{CONCLUSION}


Based on the description given in section 4 regarding the results and discussion of the research, to provide answers to the problem formulation and research objectives, the conclusions can be drawn as the following:

After the analysis with a dynamic system, three scenarios were obtained to minimize the possibility of the rework. From the results of the repair scenario model using a dynamic system, it shows that the rework cost efficiency in the Maximum is $17.41 \%$

\section{ACKNOWLEDGEMENT}

Thank you to the supervisor that the author is able to complete this research, this research is funded by the author's own expenses. Author would also like to thank all the master students of civil engineering at Mercu Buana University Jakarta for their support in completing this research.

\section{REFERENCE}

[1] A. E. Husin, M. A. Berawi, S. Dikun, T. Ilyas, and A. R. B. Berawi, "Forecasting demand on mega infrastructure projects: Increasing financial feasibility," Int. J. Technol., vol. 6, no. 1, pp. 73-83, 2015, doi: 10.14716/ijtech.v6i1.782.

[2] R. W. M. Wong, "The construction of deep and complex basements under extremely difficult urban environment-3 representing projects in Hong Kong," Adv. Build. Technol., vol. 1, pp. 713-721, 2002, doi: 10.1016/b978-0080441009/50090-5.

[3] R. continues to affect both cost and schedule performance throughout the construction industry. T. direct costs Alone et al., "Measuring the Impact of Rework on Construction.pdf," no. March, pp. 187-198, 2009, [Online]. Available: https://ascelibrary.org/doi/10.1061/\%28ASCE\%290733-9364\%282009\%29135\%3A3\%28187\%29.

[4] B. G. Hwang, X. Zhao, and K. J. Goh, "Investigating the client-related rework in building projects: The case of Singapore,” Int. J. Proj. Manag., vol. 32, no. 4, pp. 698-708, 2014, doi: 10.1016/j.ijproman.2013.08.009.

[5] M. Marzouk, M. Abdelhamid, and M. Elsheikh, "Selecting sustainable building materials using system dynamics and ant colony optimization," J. Environ. Eng. Landsc. Manag., vol. 21, no. 4, pp. 237-247, 2013, doi: 10.3846/16486897.2013.788506.

[6] S. Kermanshachi, R. Thakur, and P. Govan, "Discovering the Impact of Late Change Orders and Rework on Labor Productivity: A Water Treatment Case Study Analysis Using System Dynamics Modeling," Constr. Res. Congr. 2018 Infrastruct. Facil. Manag. - Sel. Pap. from Constr. Res. Congr. 2018, vol. 2018-April, pp. 691-701, 2018, doi: 10.1061/9780784481295.069.

[7] A. F. Abdolvandi, A. Parsamehr, H. Babazadeh, S. Eslamian, and E. Z. Hosseinipour, "Conjunctive Use of Surface and Groundwater Resources Using System Dynamics Approach: Case Study of Namroud Dam," World Environ. Water Resour. Congr. 2014 Water Without Borders - Proc. 2014 World Environ. Water Resour. Congr., pp. 323-334, 2014, doi: 10.1061/9780784413548.035.

[8] F. Ullah, M. J. Thaheem, S. M. E. Sepasgozar, and N. Forcada, "System Dynamics Model to Determine Concession Period of PPP Infrastructure Projects: Overarching Effects of Critical Success Factors," J. Leg. Aff. Disput. Resolut. Eng. Constr., vol. 10, no. 4, p. 04518022, 2018, doi: 10.1061/(asce)la.1943-4170.0000280.

[9] H. Leon, H. Osman, M. Georgy, and M. Elsaid, "System Dynamics Approach for Forecasting Performance of Construction Projects,” J. Manag. Eng., vol. 34, no. 1, p. 04017049, 2018, doi: 10.1061/(asce)me.1943-5479.0000575.

[10] F. Jalaei and A. Jrade, “Construction Research Congress 2014 CASCE 2014 140,” Constr. Res. Congr. 2014, no. 2008, pp. 140-149, 2014, doi: 10.1061/9780784413517.176.

[11] S. Mortazavi, A. Kheyroddin, and H. Naderpour, "Risk Evaluation and Prioritization in Bridge Construction Projects Using System Dynamics Approach,” Pract. Period. Struct. Des. Constr., vol. 25, no. 3, p. 04020015, 2020, doi: 10.1061/(asce)sc.1943-5576.0000493.

[12] R. Rashedi and T. Hegazy, "Holistic Analysis of Infrastructure Deterioration and Rehabilitation Using System Dynamics,” J. Infrastruct. Syst., vol. 22, no. 1, p. 04015016, 2016, doi: 10.1061/(asce)is.1943-555x.0000273.

[13] D. F. Gillespie, K. J. Robards, and S. Cho, "Designing Safe Systems: Using System Dynamics to Understand Complexity," Nat. Hazards Rev., vol. 5, no. 2, pp. 82-88, 2004, doi: 10.1061/(asce)1527-6988(2004)5:2(82). 
[14] K. Zhou, J. G. Duan, ; Abigail Rosenberg, and J. Shim, "World Environmental and Water Resources Congress," vol. 1, no. i, p. 489, 2018.

[15] Husin, A. E., \& Sulistyaningtyas, C. B. (2019). project by M-PERT utilization Time performance improvement of hospital building structure construction project by M-PERT utilization. 